\title{
Investigation of the Genotoxicity of Tatrazine and Anti-Genotoxicity of Some Plants Extracts in Drosophila Melanogaster Using the Smart Test
}

\author{
Aylin YILMAZ ÇETINKAYA ${ }^{1^{*}} \quad$ Selçuk YURTSEVER ${ }^{2}$ \\ 1.Keşan Hakkı Yörük School of Health, Turkey Trakya University, 22800 Keşan, Turkey \\ 2.Biology Department, Science Faculty, Turkey Trakya University, 22030 Edirne. Turkey \\ * E-mail of the corresponding author: aylincetinkaya@trakya.edu.tr
}

\begin{abstract}
Food colorings are the food additives, which are used for improving the appearance of food and beverages. In the present study, genotoxic effects of Tatrtazine (E 102), is an synthetic food coloring, was investigated in vivo using the wing spot test, SMART (somatic mutation and recombination test), in Drosophila melanogaster Meigen. The food coloring at 25\%, 50\% and $75 \%$ concentrations were added to food mediums of Drosophila during the larval stage and the numbers of mutant wing spots were evaluated using the SMART. Negative control medium was prepared with distilled water, while positive control medium was prepared with $1 \mathrm{mM}$ EMS (ethyl methane sulfonate). According to results obtained from SMART, Tartrazine demonstrated significant results in trans-heterozygous flies $(\mathrm{mwh} / \mathrm{flr} 3)$ for inducing the mutant wing spots compared to control groups at $25 \mathrm{mg} / \mathrm{ml}, 50 \mathrm{mg} / \mathrm{ml}$, and $75 \mathrm{mg} / \mathrm{ml}$ exposure concentrations. On the other hand, Tartrazine yielded significant results for inducing the mutant wing spots in balancer-heterozygous flies (mwh/TM3) at $25 \mathrm{mg} / \mathrm{ml}, 50 \mathrm{mg} / \mathrm{ml}$, and $75 \mathrm{mg} / \mathrm{ml}$ exposure concentrations. The numbers of mutant wing spots were increased by the food coloring depending on the concentration (Chi-Square test; $\mathrm{df}=3, \mathrm{P}<0.001$ ). It was also determined that the numbers of mutant wing spots were significantly higher than the flies in the negative control medium and it suggests that Tartrazine has genotoxic effect. However, these numbers were less than the flies in the positive control medium; the data indicate that genotoxic effect of the food coloring was not as much as the EMS.On the other hand, the concentrations of Tartrazine were used in the mediums together the different plant extracts to determine whether they have anti-genotoxic effects against the food coloring. The following plant extracts were added to mediums at $100 \mathrm{mg} / \mathrm{ml}$ concentration with the food coloring was: Hypericum perforatum L., (St John's wort), Silybum marianum (L.) Gaertn. (milk thistle), and Lavandula stoechas L. (topped lavender). When the mutant wing spots were compared to the control groups showed that the three plant extracts have no effect to reduce numbers of mutant wing spots in trans-heterozygous flies (mwh/flr3) and in balancer-heterozygous flies (mwh/TM3) and thus, have no anti-genotoxic effect against the food coloring used experimental treatments (Kruskal-Wallis test; $\mathrm{df}=2, \mathrm{P}>0.05)$.
\end{abstract}

Keywords:Genotoxicity, anti-genotoxicity, Tartrazine, Hypericum perforatum L., Silybum marianum (L.) Gaertn., Lavandula stoechas L., Drosophila melanogaster Meigen, SMART.

DOI: $10.7176 / \mathrm{JHMN} / 89-04$

Publication date:May $31^{\text {st }} 2021$

\section{Introduction}

In addition to the nutritional values of consumed food, its safety and effects on human health are nowadays widely discussed (ALKAN \& ANLAS, 2015). With the new technologies used in the food industry and the increasing variety of products, the interest in ready-made foods is increasing day-by-day with consumer demand (AKBULUT, 2011). Food additives are frequently found in ready-to-eat foods and are among the potentially important genotoxic agents (VURAL, 2005; ALKAN \& ANLAS, 2015).

Synthetic food colorings, which are commonly used class food additives, can create genotoxic effects, as well as health problems such as allergic reactions, skin rashes, asthma, hyperactivity, and concentration disorder when not used within the legal restrictions (YENTUR et al., 1996). It is also stated that the food coloring agents cause hypersensitivity, migraine, preterm delivery, salicylate sensitivity, and cancer (MAIER et al., 2010). With genotoxicity tests and epidemiological studies on Drosophila, mouse, rat, and bacteria, when not used within the limits specified in regulations, the synthetic food colorings have been reported to be carcinogenic when used in order to imitate the high quality (YENTUR et al., 1996; SARIKAYA et al., 2010). It has been determined that the level of food colorings used in studies on this subject in our country is well above the statute limits and may have harmful effects in terms of public health (YENTUR et al., 1996; TOPSOY, 1990; YAMAN, 1996).

Tartrazine used in the present study were preferred because, in the literature, there are very few scientific studies similar to the subject of the present research. There is only one previous study carried out on Tartrazine (E 102) (TRIPATHY et al., 1989) in Drosophila by using SMART. There are few studies carried out on Drosophila regarding the genotoxicity of this food coloring. 
These plant extracts used in the present study were preferred because, in the literature, there is no study carried out on the plant extracts, which are used widely among the public to eliminate mutagenic effects, in Drosophila by using SMART. There are few studies carried out on the anti-genotoxicity of Hypericum perforatum L. in Drosophila while there is no study on Silybum marianum (L.) Gaertn. and Lavandula stoechas L.

Using SMART, the present research was conducted in order to determine whether Tartrazine at $25 \mathrm{mg} / \mathrm{ml}$, $50 \mathrm{mg} / \mathrm{ml}, 75 \mathrm{mg} / \mathrm{ml}$ concentrations have a detrimental effect and Hypericum perforatum L., Silybum marianum (L.) Gaertn. and Lavandula stoechas L. at $100 \mathrm{mg} / \mathrm{ml}$ concentration have anti-genotoxic effects on D. melanogaster Meigen's mwh and flr3 lines.

\section{Materials and methods}

\subsection{Culture of Drosophila Lines}

D. melanogaster Meigen lines used in the present study were obtained from Trakya University and Akdeniz University, Science Faculty, Department of Biology. Drosophila flies were cultured in an incubator where optimum living conditions $\left(25 \pm 1^{\circ} \mathrm{C}\right.$ and $40-60 \%$ relative humidity) were provided and adjusted to 12 hours light and 12 hours dark time cycle

\subsection{Experimental Groups}

SMART method developed by (GRAF et al., 1984) was used in determining the mutagenic and/or recombinogenic effects of Tartrazine and anti-genotoxic effects of these plant extracts against the coloring on D. melanogaster Meigen lines.

\subsection{Genetic Structure of Drosophila Mutant Strains}

In Drosophila SMART, the mwh, flr3 and BdS (beaded serrate) marker genes on the third-largest chromosome of Drosophila are used. In Drosophila wing SMART, flr3/TM3, BdS virgin females and mwh/mwh males are crossed for normal metabolic activity (LINDSLEY \& GRELL 1968; LINDSLEY \& ZIMM 1992; GARCIABELLIDO \& DAPENA 1974).

Experiments in the present study were simultaneously conducted in the application groups consisting of experimental and control groups. Distilled water was used in the negative control group and, in literature, $1 \mathrm{mM}$ concentration of EMS (KASIMOĞLU \& UYSAL 2016), which was used in the positive control group, was stated to have a mutagenic effect. Tartrazine and all of the plant extracts used in the experiment groups dissolved in distilled water.

While tartrazine was used at $25 \%, 50 \%$, and $75 \%$ concentrations in the experimental group and Hypericum perforatum L., Silybum marianum (L.) Gaertn. and Lavandula stoechas L. were used at $10 \%$ concentration in treatment groups for $72 \pm 4$ hours for Drosophila larvae.

D. melanogaster Meigen lines were fed with a standard Drosophila medium when kept in stock and in a cross bottle in order to ensure the fertilization and embryogenesis to obtain heterozygous larvae. Drosophila instant medium was used for Drosophila larvae for $72 \pm 4$ hours in the experimental, treatment and control groups. Drosophila instant medium and the food coloring and the plant extracts used in the study were purchased commercially. Drosophila instant medium was procured from Carolina Biological Supply Company, Tartrazine from Parshwanath Colour Chem Group, Hypericum perforatum L. (St. John's wort) and Silybum marianum (L.) Gaertn. (milk thistle) from Solgar, Lavandula stoechas L. (topped lavender) from Herbal Pharm, and EMS from Sigma Aldrich GmbH.

\subsection{Applications in Experimental Groups}

Larvae in groups of 100 were left into falcon tubes, where $1.5 \mathrm{~g}$ of Drosophila instant medium were wetted with $5 \mathrm{ml}$ of solutions containing $25 \%, 50 \%$ and $75 \%$ concentrations of Tartrazine and/or $10 \%$ concentration of the plant extracts. While edges of wings of the adult flies developed from trans-heterozygous larvae (mwh/flr3) at each concentration all of the groups have normal structure, the edges of wings of the balancer-heterozygous flies $(\mathrm{mwh} / \mathrm{TM} 3)$ are in the form of serrate. In analyses, 40 wings were used for each concentration in each group. Slides of normal and serrate wings were examined using a light microscope under $40 \times 10$ magnification in order to detect the presence of mutant clones (KAYA, 2000). Classes by mutant clones are as follows: small single spots containing 1-2 mwh, large single spots containing $\geq 3 \mathrm{mwh}$ or $\geq 4 \mathrm{flr} 3$, and twin spots containing adjacent mwh and flr3 cells (GRAF et al., 1984).

\subsection{Statistical Analysis}

Minitab package program was used in the statistical analysis of the study results. In the data analysis, it was investigated using the Chi-Square test if the total numbers of mutant spots in the wings of the flies in the positive and negative control groups was statistically different $(\mathrm{df}=1)$. Chi-Square test $(\mathrm{df}=3)$ was also used in the 
analyzes, where the total numbers of mutant spots in the wings of the flies at three different doses in experimental groups were compared separately with the flies fed in the positive control group and negative control group. The total numbers of mutant spots in the wings of the flies in experimental and treatment groups were compared with each other and whether there was a statistical difference was determined by the Chi-Square test $(\mathrm{df}=2)$.

Possible differences between the average of the total numbers of mutant wing spots of flies grown in experimental and treatment groups were compared with Non-Parametric Kruskal-Wallis test ( $\mathrm{df}=2$ ).

The average of the total numbers of mutant spots in the normal and serrate wings of the flies in all experimental groups were compared with the Mann-Whitney U test.

The total numbers of mutant wing spots obtained from the present study and presented as Fr (frequency) values used in the analyses, and the differences below $\mathrm{P}<0.05$ were considered to be statistically significant.

\section{Results}

When the results of the present study were evaluated, the total numbers of mutant spots in normal $(\mathrm{X} 2=213.22$, $\mathrm{df}=1, \mathrm{P}<0.001$ ) wings (in Table 1) and serrate $(\mathrm{X} 2=69.06, \mathrm{df}=1, \mathrm{P}<0.001)$ wings (in Table 2 ) of Drosophila flies in the positive control group was found to be much more than those of negative control group.

SMART data obtained from experimental group studies of Tartrazine were compared with results of positive and negative control groups. The total numbers of mutant spots in the normal wings (in Table 1) and serrate wings (in Table 2) of the Drosophila flies grown in the containing with 25\%o, 50\%o and 75\%o concentrations of Tartrazine is higher than those grown in the medium prepared with distilled water (normal wings: $\mathrm{X} 2=22.43, \mathrm{df}=3, \mathrm{P}<0.001$; serrate wings: $\mathrm{X} 2=29.91, \mathrm{df}=3, \mathrm{P}<0.001$ ) but it was found to be less than those grown in medium with EMS addition (normal wings: $\mathrm{X} 2=324.56, \mathrm{df}=3, \mathrm{P}<0.001$; serrate wings: $\mathrm{X} 2=65.19$, $\mathrm{df}=3$, $\mathrm{P}<0.001)$.

Although the total numbers of mutant spots of the flies grown in the medium where Tartrazine was applied at three different concentrations increased in parallel from low concentration to high concentration, it was observed that there was no statistically difference in normal wings (in Table $1 ; \mathrm{X} 2=0.64, \mathrm{df}=2, \mathrm{P}>0.05$ ). On the other hand, it was found that the numbers of mutant spots increased in parallel with the concentrations of Tartrazine in the serrate wings (in Table 2; X2 $=11.21, \mathrm{df}=2, \mathrm{P}<0.01$ ). The total numbers of mutant spots of the wings increased gradually due to the concentrations of Tartrazine in all of the results obtained from the experimental groups.

The total numbers of mutant spots in only the serrate wings of the Drosophila flies grown in the mediums having three different concentrations of Tartrazine 4R with Hypericum perforatum L. at $10 \%$ concentration was higher than grown that of the flies in the medium prepared with distilled water (serrate wings in Table 2: $\mathrm{X} 2=13.56, \mathrm{df}=3, \mathrm{P}<0.01$; normal wings in Table $1: \mathrm{X} 2=11.48, \mathrm{df}=3, \mathrm{P}>0.05$ ) but it was found to be less than those grown in medium added to EMS (normal wings in Table 1: $\mathrm{X} 2=438.41, \mathrm{df}=3, \mathrm{P}<0.001$; serrate wings in Table 2: $\mathrm{X} 2=75.28, \mathrm{df}=3, \mathrm{P}<0.001)$.

The total numbers of mutant spots in the normal and serrate wings of the Drosophila flies grown in the mediums with three different concentrations of Tartrazine 4R and 10\% concentration of Silybum marianum (L.) Gaertn. were more than that of the flies grown in medium containing distilled water (normal wings in Table 1: $\mathrm{X} 2=15.41, \mathrm{df}=3, \mathrm{P} \leq 0.001$; serrat wings in Table $2: \mathrm{X} 2=11.88, \mathrm{df}=3, \mathrm{P}<0.01$ ) but it was found to be lower than those grown in medium with EMS (normal wings in Table 1: $\mathrm{X} 2=413.24$, $\mathrm{df}=3, \mathrm{P}<0.001$; serrate wings in Table 2: $\mathrm{X} 2=80.12, \mathrm{df}=3, \mathrm{P}<0.001)$.

The total numbers of mutant spots in the normal and serrate wings of the Drosophila flies grown in the mediums having three different concentrations of Tartrazine with Lavandula stoechas L. at $10 \%$ concentration were lower than that of the flies grown in the medium prepared with distilled water (normal wing in Table 1: $\mathrm{X} 2=7.32, \mathrm{df}=3, \mathrm{P}>0.05$; serrate wing in Table 2: $\mathrm{X} 2=11.98, \mathrm{df}=3, \mathrm{P}<0.01$ ) but it was found to be less than those grown in medium with EMS (normal wing in Table 1: $\mathrm{X} 2=448.25, \mathrm{df}=3, \mathrm{P}<0.001$; serrate wing in Table 2: $\mathrm{X} 2=92.45, \mathrm{df}=3, \mathrm{P}<0.001)$

Statistical analyses showed that total numbers of mutant spots in the wings of the flies in all experimental and treatment groups increased gradually depending on the concentration of Tartrazine.

While numerical differences between the total numbers of mutant spots in the normal and serrate wings of the flies were evaluated in the experimental group with three different concentrations of Tartrazine (X2=0.64 $\mathrm{df}=2, \mathrm{P}>0.05$ ), in treatment group in which three different concentrations of Tartrazine and Hypericum perforatum L. $(\mathrm{X} 2=3.20 \mathrm{df}=2, \mathrm{P}>0.05$ and in treatment group in which three different concentrations of Tartrazine and Silybum marianum (L.) Gaertn. (X2=4.32 df=2, $\mathrm{P}>0.05)$ and in treatment group in which three different concentrations of Tartrazine and Lavandula stoechas $\mathrm{L}$. $(\mathrm{X} 2=0.48, \mathrm{df}=2, \mathrm{P}>0.05)$ had not statistical significance. In other words, the total numbers of mutant wing spots within themselves of the treatment groups in which Tartrazine and the plant extracts did not significant differences. However, statistical differences of the total numbers of mutant spots in the serrate wings of the flies were significant depend on the concentration in the 
experimental group $(\mathrm{X} 2=11.21 \mathrm{df}=2, \mathrm{P}<0.01)$, in the treatment group in which Tartrazine and seperately Hypericum perforatum $\mathrm{L}$. $(\mathrm{X} 2=1.64 \mathrm{df}=2, \mathrm{P}>0.05)$, in the treatment group with Tartrazine and Silybum marianum (L.) Gaertn. (X2=1.23 df=2, $\mathrm{P}>0.05)$ and in the treatment group with Tartrazine and Lavandula stoechas L. $(\mathrm{X} 2=3.22, \mathrm{df}=2, \mathrm{P}>0.05)$.

When average numbers of mutant spots in normal wings $(\mathrm{H}=6.19 ; \mathrm{df}=3, \mathrm{P}>0.05)$ and serrate wings $(\mathrm{H}=2.20$; $\mathrm{df}=3, \mathrm{P}>0.05)$ of flies in the experimental group with three different concentrations of Tartrazine and in the treatment groups in which three different concentrations of Tartrazine were together with separately Hypericum perforatum L., Silybum marianum (L.) Gaertn., Lavandula stoechas L. were compared with each other, it was observed that results found were not different.

Finally, when average of total numbers of mutant spots in the normal and serrate wings of the flies in the experimental and treatment groups were compared with each other, it was revealed to be not statistically differences $(\mathrm{P}>0.05)$.

Table 1. Mutant clones in mwh/flr3 wings obtained from experimental group, treatment group, positive and negative control groups.

\begin{tabular}{|c|c|c|c|c|c|c|c|c|c|c|c|c|}
\hline \multirow[t]{2}{*}{$\begin{array}{c}\text { Application } \\
\text { groups/ } \\
\text { Concentration }(\mathrm{mg} / \mathrm{ml}) \\
\end{array}$} & \multirow[t]{2}{*}{ Wing } & \multicolumn{2}{|c|}{$\begin{array}{l}\text { Small single spots } \\
\quad(1-2 \text { cell })\end{array}$} & \multicolumn{2}{|c|}{$\begin{array}{l}\text { Large single spots } \\
\quad(>2 \text { cell })\end{array}$} & \multicolumn{2}{|c|}{ Twin spots } & \multicolumn{2}{|c|}{ Total mwh spots } & \multicolumn{3}{|c|}{ Total spots ${ }^{\mathrm{X} 2}$} \\
\hline & & No & $\mathrm{Fr}$ & No & $\mathrm{Fr}$ & No & $\mathrm{Fr}$ & No & $\mathrm{Fr}$ & No & $\mathrm{Fr}$ & \\
\hline Distilled water & 40 & 3 & $(0.08)$ & 5 & $(0.13)$ & 4 & $(0.13)$ & 3 & $(0.08)$ & 12 & $(0.30)$ & \\
\hline $1 \mathrm{mM}$ EMS & 40 & 49 & $(1.23)$ & 130 & $(3.25)$ & 68 & $(1.70)$ & 99 & $(2.48)$ & 247 & $(6.18)$ & $a^{* * *}$ \\
\hline 25 Tartrazine & 40 & 0 & $(0.00)$ & 40 & $(1.00)$ & 0 & $(0.00)$ & 1 & $(0.03)$ & 40 & $(1.00)$ & $\mathrm{a}^{* * *} \mathrm{~b}^{* * *}$ \\
\hline 50 Tartrazine & 40 & 3 & $(0.08)$ & 44 & $(1.10)$ & 0 & $(0.00)$ & 5 & $(0.13)$ & 47 & $(1.18)$ & $\mathrm{a}^{* * *} \mathrm{~b}^{* * *}$ \\
\hline \begin{tabular}{|l|}
75 Tartrazine \\
\end{tabular} & 40 & 4 & $(0.10)$ & 42 & $(1.05)$ & 0 & $(0.00)$ & 4 & $(0.10)$ & 46 & $(1.15)$ & $a^{* * *} b^{* * *}$ \\
\hline 25 Tartrazine-H. perforatum & 40 & 0 & $(0.00)$ & 20 & $(0.50)$ & 0 & $(0.00)$ & 0 & $(0.00)$ & 20 & $(0.50)$ & $\mathrm{b}^{* * *}$ \\
\hline 50 Tartrazine-H. perforatum & 40 & 1 & $(0.03)$ & 31 & $(0.78)$ & 0 & $(0.00)$ & 2 & $(0.05)$ & 32 & $(0.80)$ & $b^{* * *}$ \\
\hline 75 Tartrazine-H. perforatum & 40 & 2 & $(0.05)$ & 29 & $(0.73)$ & 0 & $(0.00)$ & 2 & $(0.05)$ & 31 & $(0.78)$ & $b^{* * *}$ \\
\hline 25 Tartrazine-S. marianum & 40 & 1 & $(0.03)$ & 23 & $(0.58)$ & 0 & $(0.00)$ & 2 & $(0.05)$ & 24 & $(0.60)$ & $\mathrm{a}^{* * *} \mathrm{~b}^{* * *}$ \\
\hline 50 Tartrazine-S. marianum & 40 & 3 & $(0.08)$ & 37 & $(0.93)$ & 0 & $(0.00)$ & 4 & $(0.10)$ & 40 & $(1.00)$ & $a^{* * *} b^{* * *}$ \\
\hline 75 Tartrazine-S. marianum & 40 & 1 & $(0.03)$ & 28 & $(0.70)$ & 0 & $(0.00)$ & 1 & $(0.03)$ & 29 & $(0.73)$ & $\mathrm{a}^{* * *} \mathrm{~b}^{* * *}$ \\
\hline 25 Tartrazine-L. stoechas & 40 & 7 & $(0.18)$ & 17 & $(0.43)$ & 0 & $(0.00)$ & 7 & $(0.18)$ & 24 & $(0.60)$ & $\mathrm{b}^{* * *}$ \\
\hline 50 Tartrazine-L. stoechas & 40 & 2 & $(0.05)$ & 25 & $(0.63)$ & 2 & $(0.05)$ & 2 & $(0.05)$ & 29 & $(0.73)$ & $b^{* * *}$ \\
\hline 75 Tartrazine-L. stoechas & 40 & 0 & $(0.00)$ & 26 & $(0.65)$ & 0 & $(0.00)$ & 0 & $(0.00)$ & 26 & $(0.65)$ & $b^{* * *}$ \\
\hline $\mathrm{H}, \mathrm{P}^{\#}$ & & & & & & & & & & & & $6.19,>0.05$ \\
\hline $\mathrm{P} \S$ & & & & & & & & & & & & $>0.05$ \\
\hline
\end{tabular}

No: Numbers of mutant clones, Fr: Frequency; \#: It was evaluated by Kruskal-Wallis test;

$\S$ : It was evaluated by Mann-Whitney U test; X2: In evaluation with Chi-Square test; a: with Distilled water, b: with EMS, c: with Tartrazine; *: $\mathrm{P}<0.05$, **: $\mathrm{P}<0.01, * * *$ : $\mathrm{P}<0.001$

Table 2. Mutant clones in mwh/TM3 wings obtained from experimental group, treatment group, positive and negative control groups.

\begin{tabular}{|c|c|c|c|c|c|c|c|c|c|c|c|c|}
\hline \multirow[t]{2}{*}{$\begin{array}{c}\text { Application } \\
\text { groups/ } \\
\text { Concentration }(\mathrm{mg} / \mathrm{ml}) \\
\end{array}$} & \multirow[t]{2}{*}{ Wing } & \multicolumn{2}{|c|}{$\begin{array}{c}\text { Small single } \\
\text { spots } \\
(1-2 \text { cell }) \\
\end{array}$} & \multicolumn{2}{|c|}{$\begin{array}{c}\text { Large single } \\
\text { spots } \\
(>2 \text { cell }) \\
\end{array}$} & \multicolumn{2}{|c|}{$\begin{array}{l}\text { Twin } \\
\text { spots }\end{array}$} & \multicolumn{2}{|c|}{$\begin{array}{l}\text { Total mwh } \\
\text { spots }\end{array}$} & \multicolumn{3}{|c|}{ Total spots $\mathrm{X} 2$} \\
\hline & & No & $\mathrm{Fr}$ & No & $\mathrm{Fr}$ & No & $\mathrm{Fr}$ & No & $\mathrm{Fr}$ & No & $\mathrm{Fr}$ & \\
\hline Distilled water & 40 & 1 & $(0.03)$ & 6 & $(0.15)$ & 0 & $(0.00)$ & 1 & $(0.03)$ & 7 & $(0.18)$ & \\
\hline $1 \mathrm{mM}$ EMS & 40 & 22 & $(0.55)$ & 66 & $(1.65)$ & 0 & $(0.00)$ & 71 & $(1.78)$ & 88 & $(2.20)$ & $a^{* * *}$ \\
\hline 25 Tartrazine & 40 & 1 & $(0.03)$ & 18 & $(0.45)$ & 0 & $(0.00)$ & 2 & $(0.05)$ & 19 & $(0.48)$ & $\mathrm{a}^{* * *} \mathrm{~b}^{* * *} \mathrm{c} * *$ \\
\hline 50 Tartrazine & 40 & 0 & $(0.00)$ & 26 & $(0.65)$ & 0 & $(0.00)$ & 0 & $(0.00)$ & 26 & $(0.65)$ & $\mathrm{a}^{* * *} \mathrm{~b}^{* * *} \mathrm{c}^{* *}$ \\
\hline 75 Tartrazine & 40 & 4 & $(0.10)$ & 40 & $(1.00)$ & 0 & $(0.00)$ & 6 & $(0.15)$ & 44 & $(1.10)$ & $a^{* * *} b^{* * *} c^{* *}$ \\
\hline $\begin{array}{ll}25 & \text { Tartrazine-H. } \\
\text { perforatum } & \end{array}$ & 40 & 3 & $(0.08)$ & 17 & $(0.43)$ & 0 & $(0.00)$ & 3 & $(0.08)$ & 20 & $|(0.50)|$ & $a^{* * *} b^{* * *}$ \\
\hline $\begin{array}{ll}50 & \text { Tartrazine- } \mathrm{H} . \\
\text { perforatum } & \\
\end{array}$ & 40 & 3 & $(0.08)$ & 22 & $(0.55)$ & 0 & $(0.00)$ & 4 & $(0.10)$ & 25 & $(0.63)$ & $a^{* * *} b^{* * *}$ \\
\hline $\begin{array}{ll}75 & \text { Tartrazine-H. } \\
\text { perforatum } & \\
\end{array}$ & 40 & 3 & $(0.08)$ & 26 & $(0.65)$ & 0 & $(0.00)$ & 3 & $(0.08)$ & 29 & $(0.73)$ & $a^{* * *} b^{* * *}$ \\
\hline 25 Tartrazine-S. marianum & 40 & 1 & $(0.03)$ & 18 & $(0.45)$ & 0 & $(0.00)$ & 1 & $(0.03)$ & 19 & $(0.48)$ & $\mathrm{a}^{* * *} \mathrm{~b}^{* * *}$ \\
\hline 50 Tartrazine-S. marianum & 40 & 3 & $(0.08)$ & 22 & $(0.55)$ & 0 & $(0.00)$ & 4 & $(0.10)$ & 25 & $(0.63)$ & $\mathrm{a}^{* * *} \mathrm{~b}^{* * *}$ \\
\hline 75 Tartrazine-S. marianum & 40 & 3 & $(0.08)$ & 23 & $(0.58)$ & 0 & $(0.00)$ & 3 & $(0.08)$ & 26 & $(0.65)$ & $a^{* * *} b^{* * *}$ \\
\hline
\end{tabular}




\begin{tabular}{|c|c|c|c|c|c|c|c|c|c|c|c|}
\hline 25 Tartrazine-L. stoechas & 40 & 3 & $(0.08)$ & 11 & $(0.28)$ & 0 & $(0.00)$ & 3 & $(0.08)$ & \begin{tabular}{|l|l|}
14 & $(0.35)$ \\
\end{tabular} & $\mathrm{a}^{* * *} \mathrm{~b}^{* * *}$ \\
\hline 50 Tartrazine-L. stoechas & 40 & 3 & $(0.08)$ & 21 & $(0.53)$ & 0 & $(0.00)$ & 3 & $(0.08)$ & \begin{tabular}{|l|l|}
24 & $(0.60)$ \\
\end{tabular} & $\mathrm{a}^{* * *} \mathrm{~b}^{* * *}$ \\
\hline 75 Tartrazine-L. stoechas & 40 & 3 & $(0.08)$ & 21 & $(0.53)$ & 0 & $(0.00)$ & 3 & $(0.08)$ & \begin{tabular}{|l|l|}
24 & $(0.60)$ \\
\end{tabular} & $\mathrm{a}^{* * *} \mathrm{~b}^{* * *}$ \\
\hline $\mathrm{H}, \mathrm{P}^{\#}$ & & & & & & & & & & & $2.20,>0.05$ \\
\hline $\mathrm{P}^{\S}$ & & & & & & & & & & & $<0.05$ \\
\hline
\end{tabular}

No: Numbers of clones, Fr: Frequency, \#: It was evaluated by Kruskal-Wallis test; $§:$ It was evaluated by MannWhitney U test; X2: In evaluation with Chi-Square test; a: with Distilled water, b: with EMS, c: with Tartrazine, $*: \mathrm{P}<0.05, * *: \mathrm{P}<0.01, * * *: \mathrm{P}<0.001$

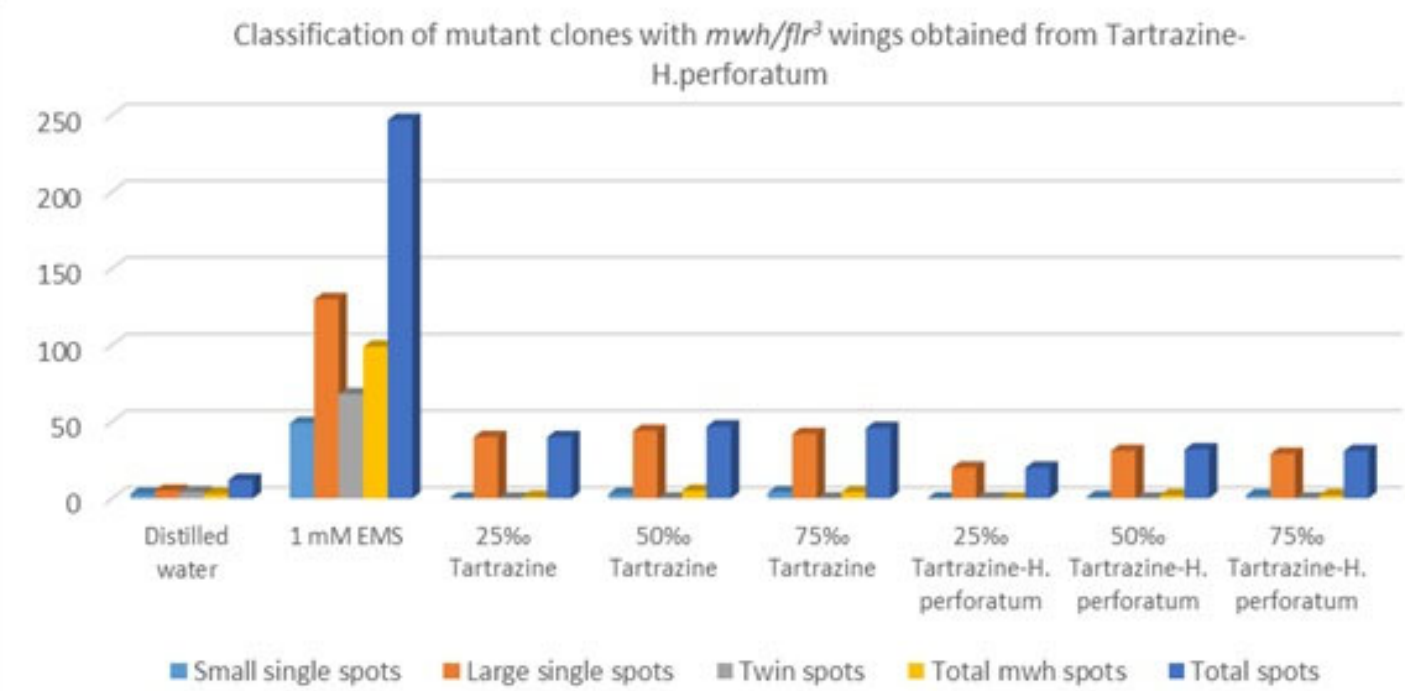

Figure 1. shows classification of mutant clones with the normal wings of the Drosophila flies in the experimental group, treatment group with Hypericum perforatum L., the positive and negative control groups.

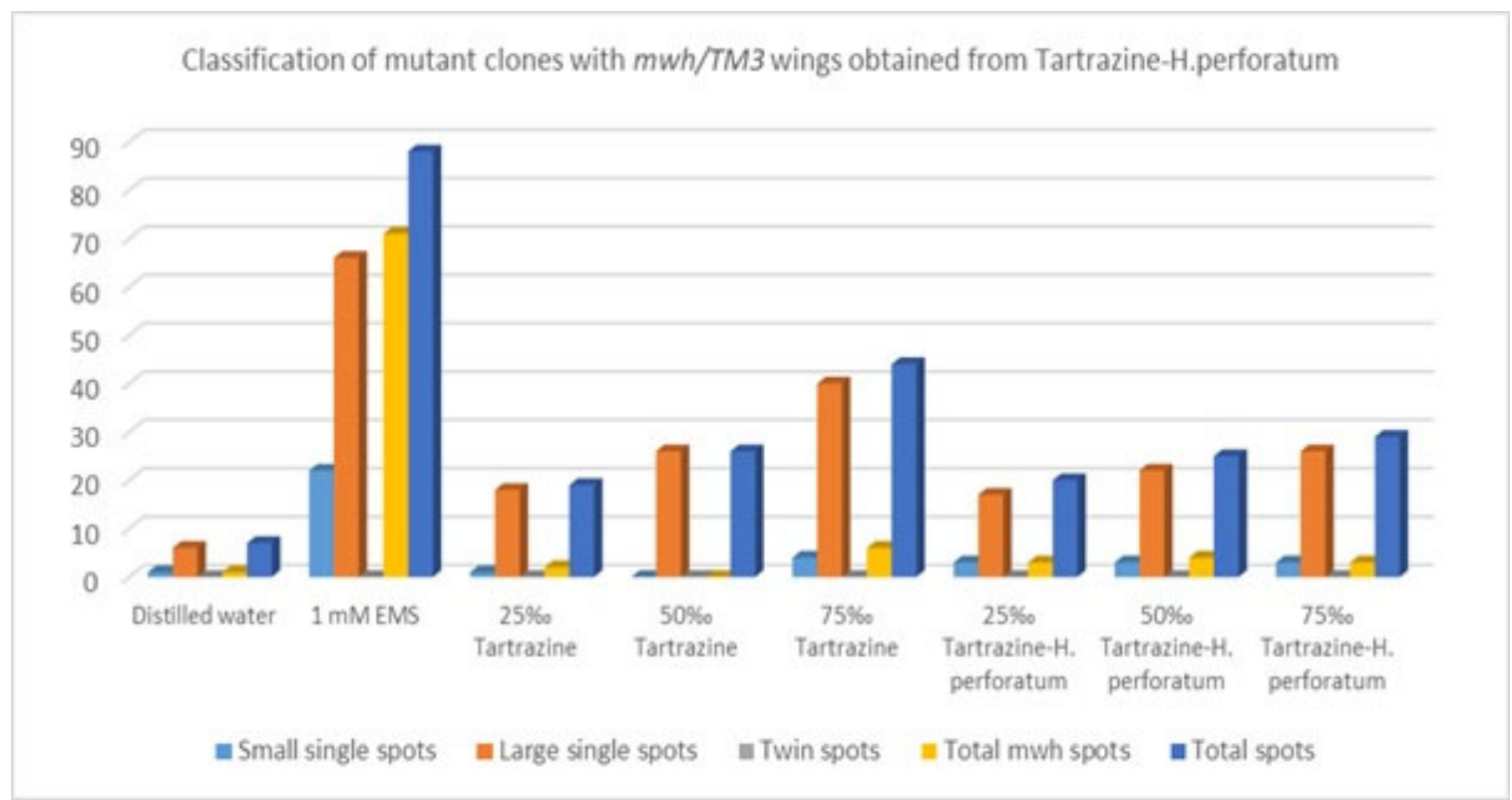

Figure 2. shows classification of mutant clones with the serrate wings of the Drosophila flies in the experimental group, treatment group with Hypericum perforatum L., the positive and negative control groups. 


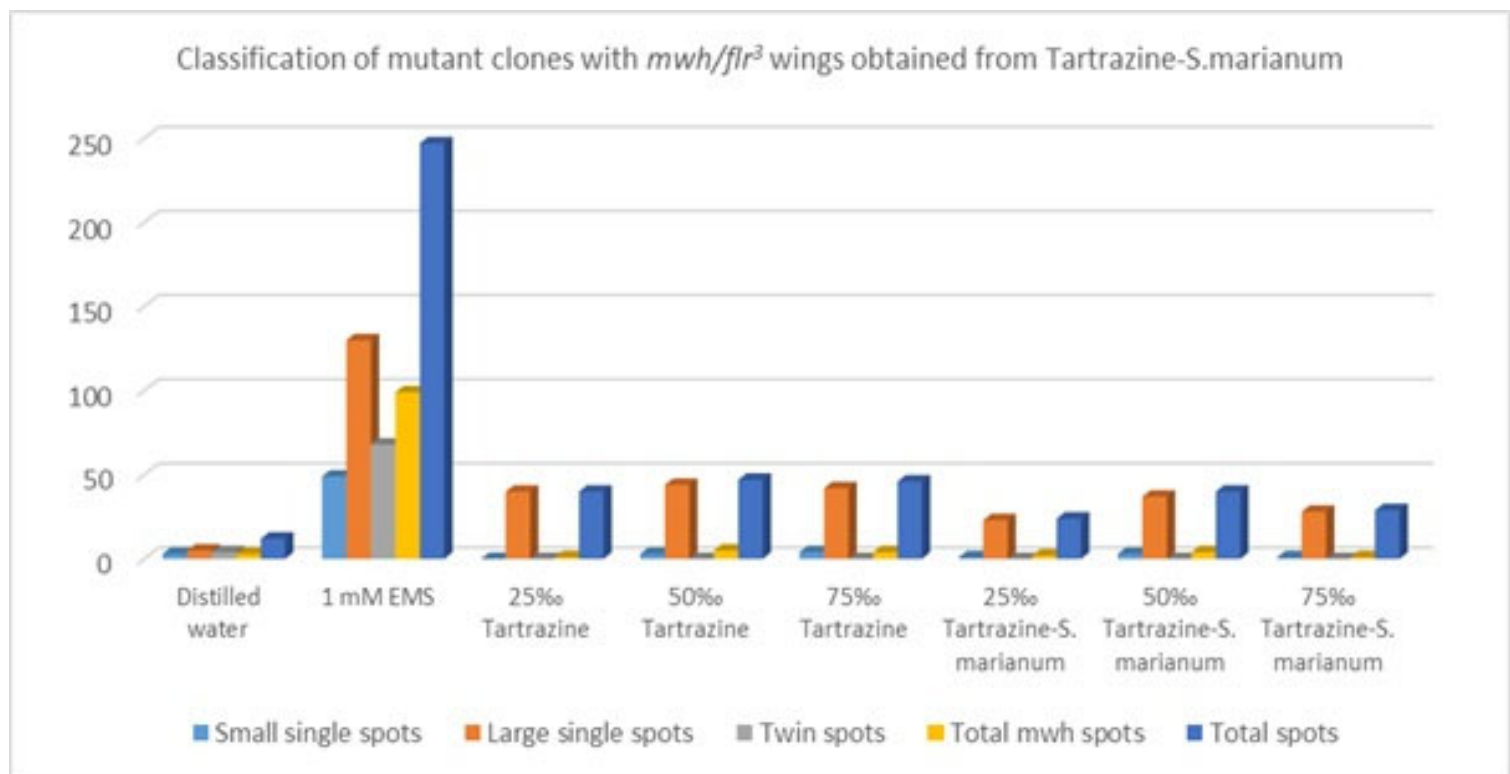

Figure 3. shows classification of mutant clones with the normal wings of the Drosophila flies in the experimental group, treatment group with Silybum marianum (L.) Gaertn., the positive and negative control groups.

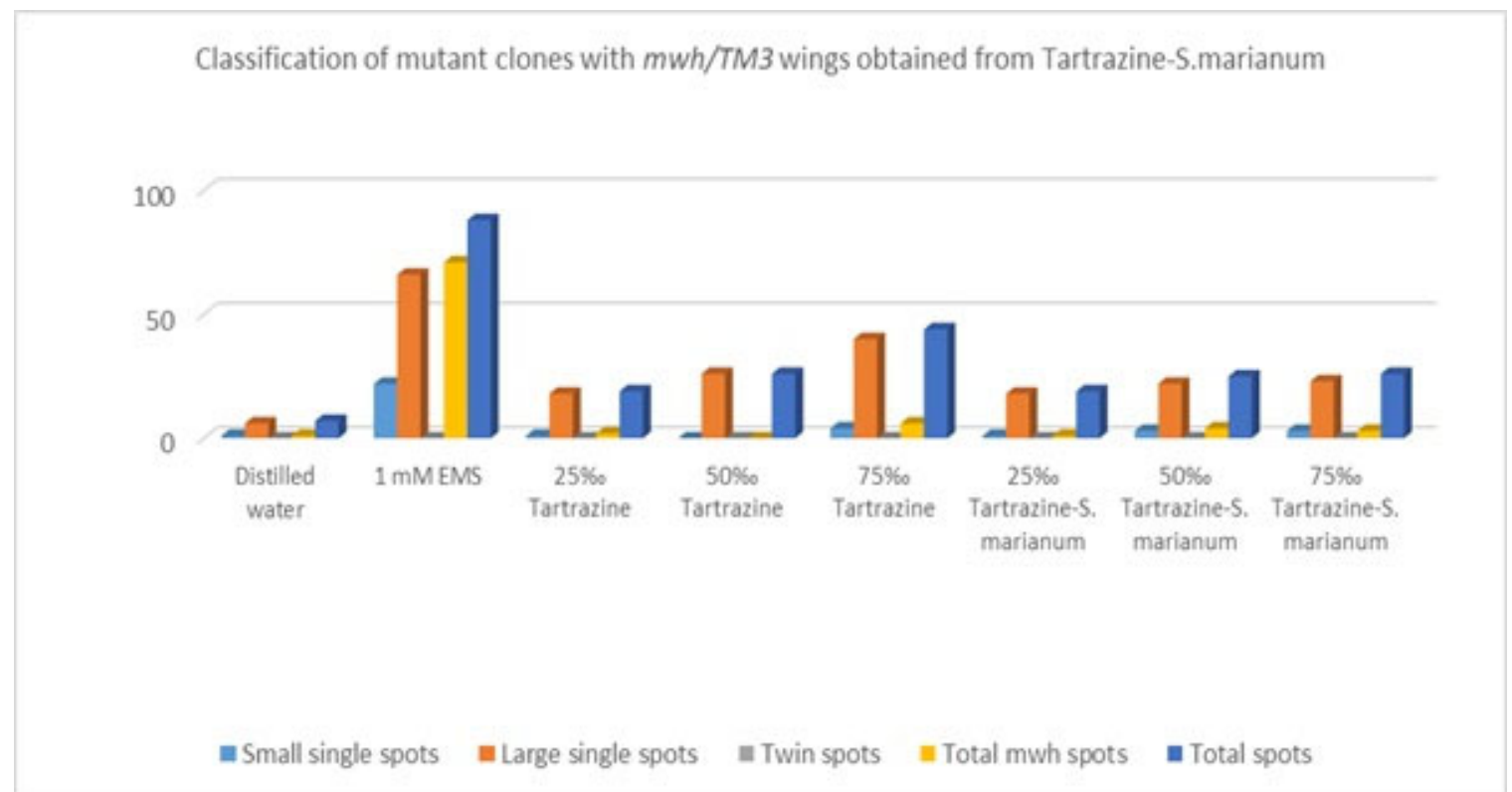

Figure 4. shows classification of mutant clones with the serrate wings of the Drosophila flies in the experimental group, treatment group with Silybum marianum (L.) Gaertn., the positive and negative control groups. 


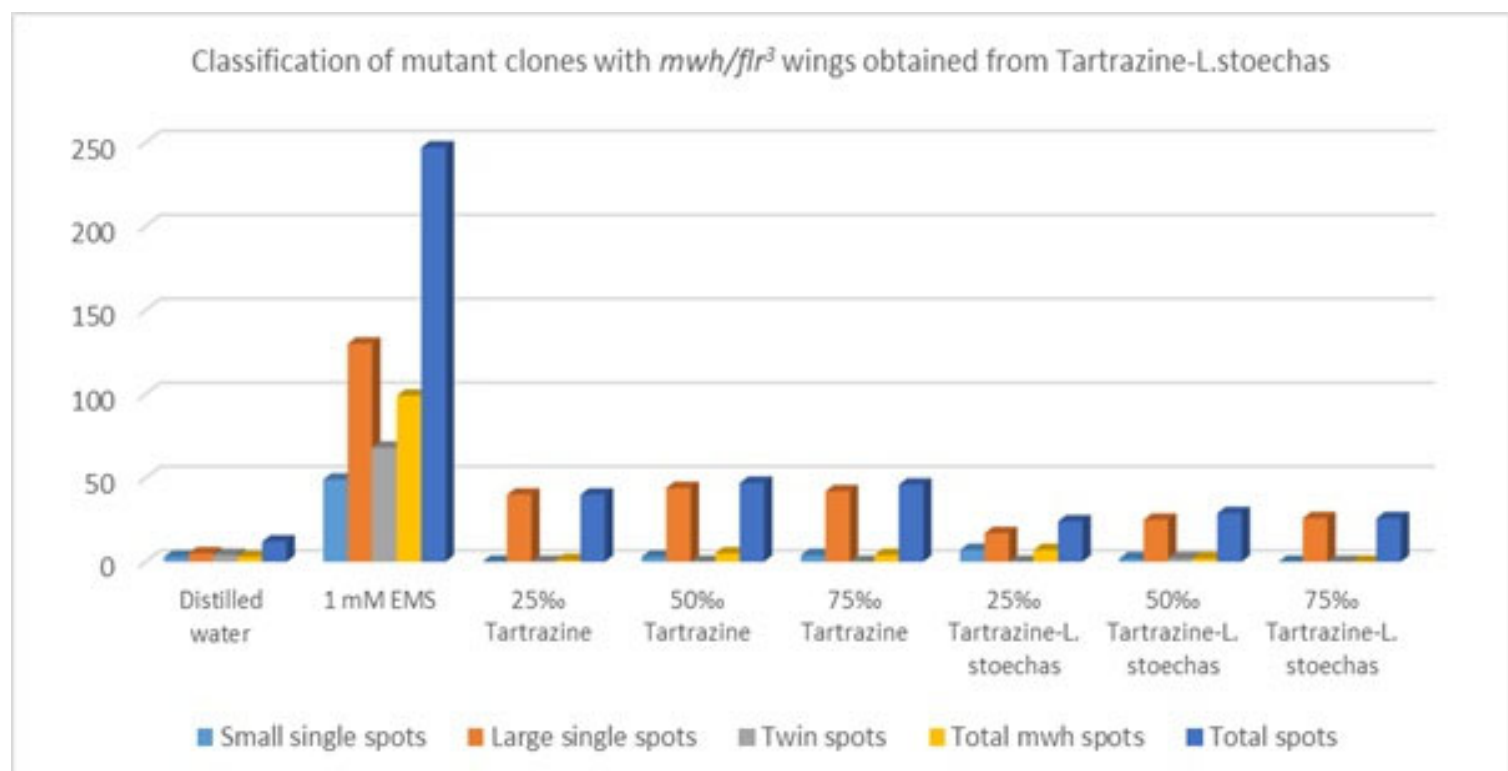

Figure 5. shows classification of mutant clones with the normal wings of the Drosophila flies in the experimental group, treatment group with Lavandula stoechas L., the positive and negative control groups.

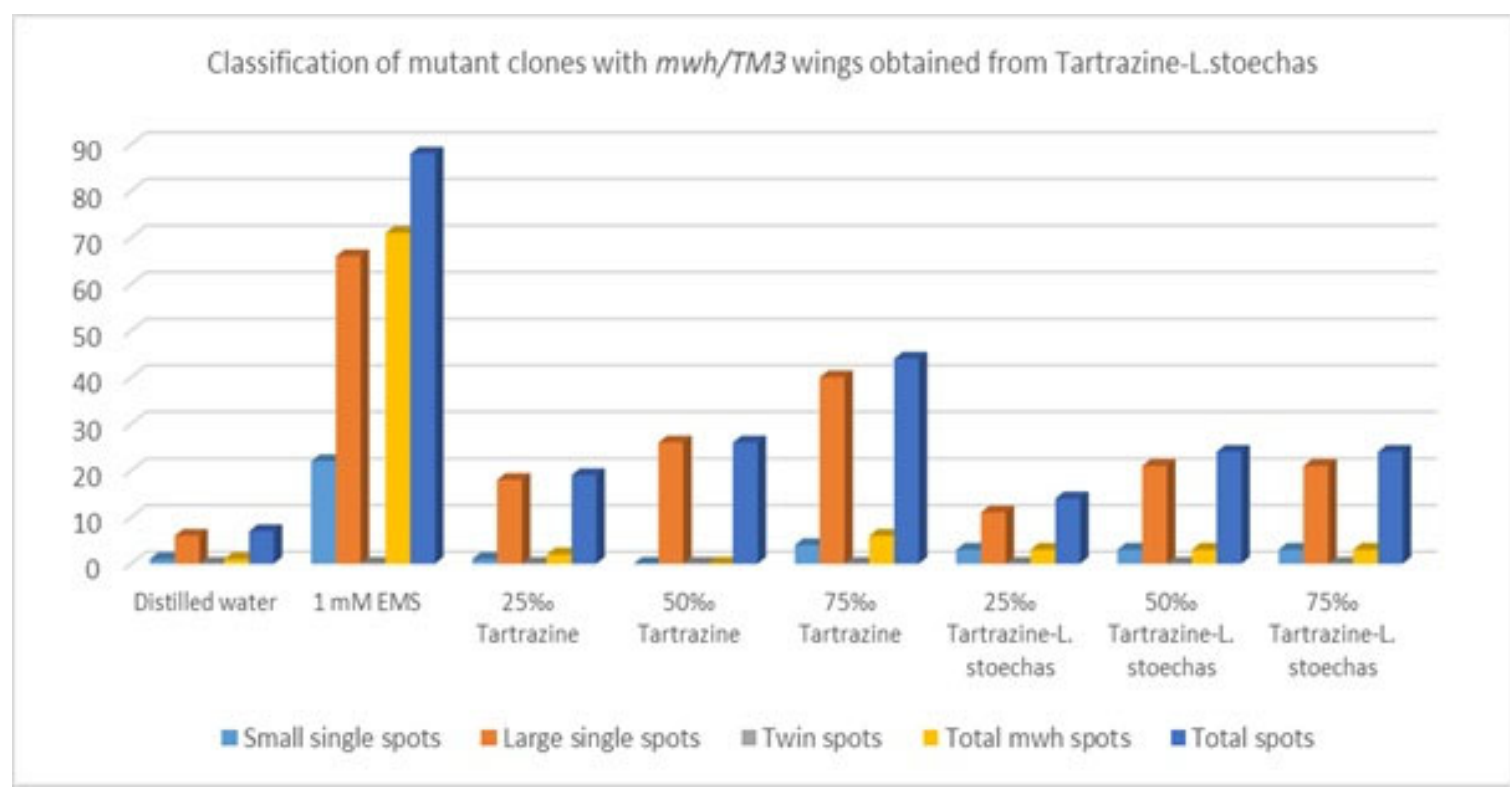

Figure 6. shows classification of mutant clones with the serrate wings of the Drosophila flies in the experimental group, treatment group with Lavandula stoechas L., the positive and negative control groups.

\section{Discussion}

Nutrition is one of the most important factors ensuring the continuity of life. Nowadays, it is seen that people's eating habits significantly differ as a result of the changes in lifestyle and economic development. Although the food additives play a significant role in the food industry, their effects on human health constitute an important issue. As a result of the increase in ready-made food consumption together with urbanization, potential health risks occur with the body's exposure to more additives (AKBULUT, 2011).

Many studies on human diseases have shown that D. melanogaster Meigen, a down-organized eukaryotic organism, can be used instead of mammals. Because, the biological properties of the imaginal disc cells in Drosophila larvae undergoing proliferation and differentiation to form body parts in the adult stage are similar to many cancer-sensitive mammalian cells, and more than $60 \%$ of genes identified in human genetic diseases are common with the genes in Drosophila genome. Drosophila is frequently included as a model organism in SMART. This test is suitable for detecting mutagenic and recombinogenic activities that are the results of genotoxic and anti-genotoxic effects in somatic cells induced by chemicals. When compared with the other tests, SMART is a quite fast, precise, and economical option (BERNARDS \& HARIHARAN, 2001). Moreover, this 
in vivo test method in Drosophila are associated with in vivo genotoxicity tests in mammals (GRAF et al., 1984; GRAF \& WURGLER, 1996). Mutations induced by chemicals in somatic cells of Drosophila larvae are transferred to daughter cells through the several cell divisions in SMART. Genotypic changes caused by a mutation or recombination in somatic cells are seen as mutant spots in the wings (GRAF et al., 1984; TRIPATHY et al., 1989).

When the present study data are evaluated using SMART, it becomes clear that Tartrazine has a mutagenic effect in normal and serrate wings of Drosophila flies at exposure concentrations. This result clearly indicates that the food coloring agent has a genotoxic effect in the imaginal disc cells that will transform into the wing spot cells during the embryonic development of Drosophila heterozygous larvae and the genotypic changes caused by mutation or recombination in somatic cells also play a role in the formation of mutant spots in the wings. Serrate wings of the fruit flies contain only clones resulting from mutation, while mutant clones resulting from both mutation and recombination can be seen in normal wings (KAYA et al., 1999; ZORDAN et al., 1994).

The mutant wing spots induced in Drosophila flies with Tartrazine are a result of the genotoxic activity of this genotoxic agent depend on its concentration. As a result of Tartrazine application in the experimental groups, it is clearly understood that Tartrazine is effective as a mutagen in the development of wing spot cells during the embryonic development of Drosophila larvae and plays a role in increasing the numbers of mutant spots in the wings. The data obtained show, when exposure concentrations of Tartrazine are applied to the fruit flies, its mutagenic effect is so strong that the numbers of mutant spots in the wings of the flies increases.

The data obtained in the present study, which clearly show the genotoxicity of Tartrazine, are supported by the following researches on the genotoxic, histopathological, and carcinogenic effects of this food coloring reported in the literature. (TRIPATHY et al., 1989) reported that Tartrazine had genotoxicity in D. melanogaster Meigen at $0.6 \%$ and $1.2 \%$ concentrations using the eye mosaic test and the wing spot test, whereas (POUL et al., 2009) using micronucleus test revealed that Tartrazine was cytotoxic and not genotoxic in mice. (SASAKI et al., 2002) determined that Tartrazine caused DNA damage in the stomach, colon, and bladder of mice depend on the dose, (MPOUNTOUKAS et al., 2010) published that Tartrazine was cytotoxic for human lymphocyte cells at 1 and $2 \mathrm{mM}$ concentrations, and (PATERSON \& BUTLER, 1982) concluded that Tartrazine applied to Muntiacus muntjac cells between mammalian fibroblast cells at 5-20 $\mu \mathrm{g} / \mathrm{ml}$ concentrations caused chromosomal disorders. The researches on the harmful effects of Tartrazine, confirm the results of the present study.

Hypericum perforatum L., Silybum marianum (L.) Gaertn. and Lavandula stoechas L. did not show reducing or preventive effects on mutations caused by Tartrazine. When the average of the total numbers of mutant spots in wings of the flies in Tartrazine treatment and experiment groups were compared with each other, it did not has any difference.

When the literature is examined, it is seen that there are a few studies about anti-genotoxicity of these plant extracts in D. melanogaster Meigen. It was also given below that similar anti-genotoxitiy studies in various model organisms about the plant extracts evaluated with different test systems.

(NEO et al., 2011) reported that H. perforatum L. at 2.5\%, 12.5\% and 50\% concentrations slowed cell death in Drosophila cells suppressing the expression of denatured proteins. (UYSAL et al., 2007) showed that H. perforatum L. at different concentrations did not cause elongation of D. melanogaster Meigen F1 progeny transformation time to adult, increased numbers of offspring due to increase at concentrations and had highest numbers of offspring at concentration of $10 \mathrm{ml} / 100 \mathrm{ml}$. (BRANDA et al., 2006) published that H. perforatum L. taken with diet was ineffective on leukopenia caused by chemotheropathic drugs on experimental cancer model induced in rats. (MARTARELLI et al., 2004) notified that while H. perforatum L. prepared in methanol $80 \%$ reduced rate of growth and development of prostate adenocarcinoma cells in humans, $70 \%$ experimental cancer induced in mice.

(CAN, 2014) reported that S. marianum (L.) Gaertn. taken with diet at $10 \%$ concentration reduced DNA damage and apoptosis in rats which liver damage induced by carbon tetrachloride. (ZHOU et al., 2006) showed that active substances of S. marianum (L.) Gaertn. was effective reducing DNA damage and regulation of cell cycle in rats. (GARCIA-MACEIRA \& MATEO, 2009) published that cervical and liver cancers in humans are inhibited by S. marianum (L.) Gaertn.

(KULCANAY, 1998) notified that when oil with leaf and flower extracts of Lavandula stoechas ssp. stoechas evaluated with Salmonella/microsome test, they were mutagenic. (AYRAL, 1997) reported that while some of essential oil compounds in above ground parts of Lavandula stoechas L. had strong cytotoxic and antibacterial effects in different cancer cells. (MARGO et al., (2006) showed that when one of the anti-genotoxic effects of Lavandula stoechas L. tested for fungistatic (delaying or inhibiting fungal growth) activity in various mushrooms, the plant extract was ineffective.

Results of the researches above mentioned and the present study data are not parallel to each other. Accordingly, the present study data show that these plant extracts were ineffective at $10 \%$ exposure concentration studied as a single concentration in protecting Drosophila flies against the genotoxicity of Tartrazine. 


\section{Conclusion}

The present study with Tartrazine can contribute to various scientific researches on toxicological, histopathological, carcinogenic, and teratogenic effects in/on various experimental organisms.

It is thought that these plant extracts can be used at different concentrations and for longer periods of time, effectiveness of the plant extracts need to determine by more basic and clinical studies and plant extracts applications together and plant extracts applications together with various drugs should be investigated.

Because disuse of the food coloring in the present study in accordance with the regulations may cause toxic effects on people, the food additives should be consumed in a more controlled manner in terms of public health by changing the nutrition habits.

\section{References}

Akbulut, M., (2011): Food additives: functions and resources. 1.Ulusal Helal ve Sağlıklı Gıda Kongresi, Kasım 19-20, 2011, Ankara, Türkiye.

Ayral M.N., (1997): Lavandula stoechas ssp. stoechas Bitkisinin Uçucu Yağının ve Uçucu Olmayan Organik Bileşenlerinin Incelenmesi ve Biyolojik Aktivitelerinin Belirlenmesi. Yüksek Lisans Tezi, Marmara Üniversitesi Fen Bilimleri Enstitüsü, İstanbul.

Branda R.F., Powden C., Brooks E.M., Yıldırım Z., Naud S.J., Mccormack J. J., (2006): Vitamin E but not St. John's wort mitigates leukopenia caused by cancer chemotherapy in rats. Transl Res., 148(6), 315-324. https://doi.org/10.1016/j.trsl.2006.05.007

Can M.İ., (2014): Karbon tetraklorür (CCl4) ile Karaciğer Hasarı Oluşturulmuş Ratlarda Deve dikeni (Silybum marianum L.)'nin Kaspaz-3, Kaspaz-9, Bax, BCL-2 Proteinlerinin Ekspresyonu ve DNA Hasarl Üzerine Etkisi. Yüksek Lisans Tezi, Fırat Üniversitesi Fen Bilimleri Enstitüsü, Elazı̆̆.

Garcia-Bellido A. \& Dapena J., (1974): Induction, detection and characterization of cell differentiation mutations in Drosophila. Mol. Gen. Genet., 128, 117-130. https://doi.org/10.1007/BF02654485

Garcia-Maceira P., Mateo J., (2009): Silibinin inhibits hypoxia-inducible factor-1a and mTOR/p70S6K/4E-BP1 signalling pathway in human cervical and hepatoma cancer cells: implications for anticancer therapy. Oncogene, 28, 313-324. https://doi.org/10.1038/onc.2008.398

Graf U., Wurgler F.E., Katz A.J., Frei H., Juan H., Hall C.B., Kale P.G., (1984): Somatic mutation and recombination test in Drosophila melanogaster. Environ. Mutagen., 6, 153-188. https://doi.org/10.1002/em.2860060206

Graf U. \& Wurgler F.E., (1996): The somatic white-ivory eye spot test does not detect the same spectrum of genotoxic events as the wing somatic mutation and recombination test in Drosophila melanogaster. Environ. Mol. Mutagen., 27, 219-226.

https://doi.org/10.1002/(sici)1098-2280(1996)27:3\%3C219::aid-em7\%3E3.0.co;2-9

Kasımoğlu C. \& Uysal H., (2016): Genoprotective effects of aqueous extracts of Rosa canina L. fruits on ethyl methanesulfonate-induced DNA damage in Drosophila melanogaster. Cumhuriyet Science Journal, 37(3), 241-247. https://doi.org/10.17776/csj.18487

Kaya B., (2000): Investigation of mutagenic and recombinogenic effects of some pesticides on Drosophila melanogaster lines. Akdeniz Üniversitesi Fen Bilimleri Enstitüsü Yayınları, Antalya, Türkiye.

Kaya B., Yanikoğlu A., Marcos R., (1999): Genotoxicity studies on the phenoxyacetates 2,4-D and 4-CPA in the Drosophila wing spot test. Teratogen. Carcinogen. and Mutagen., 19, 305-312. https://doi.org/10.1002/(SICI)1520-6866(1999)19:4\%3C305::AID-TCM7\%3E3.0.CO;2-X

Kulcanay I., (1998): Lavandula stoechas L. Bitki Ekstre ve Yağının Ames/Salmonella/Mikrozom Test Sistemi ile Mutajenitesinin Araştırılması. Yüksek Lisans Tezi, Osmangazi Üniversitesi Fen Bilimleri Enstitüsü, Eskişehir.

Lindsley D.L. \& Grell E.H., (1968): Genetic variations of Drosophila melanogaster. Carnegie Institutution of Washington Publ., Washington DC, 627, p 472. https://doi.org/10.1126/science.162.3857.993

Lindsley D.L. \& Zimm G.G., (1992): The genome of Drosophila melanogaster. Academic Press, San Diego, CA, p 1133.

Maier E., Kurz K., Jenny M., Schennach H., (2010): Food preservatives sodium benzoate and propionic acid and colourant curcumin suppress Th1-type 1956. https://doi.org/10.1002/bies.950150612

Margo A., Carolino M., Bastos M., Mexia A., (2006): Efficacy of plant extracts against stored-products fungi. Rev Iberoam Micol., 23(3), 176-178. https://doi.org/10.1016/s1130-1406(06)70039-0

Martarelli D., Martarelli B., Pediconi D., Nabissi M.I., Perfumi M., Pompei P., (2004): Hypericum perforatum methanolic extract inhibits growth of human prostatic carcinoma cell line orthotopically implanted in nude mice. Cancer Lett., 210,27-33. https://doi.org/10.1016/j.canlet.2004.01.031

Mpountoukas, P., Pantazaki, A., Kostareli, E., Christodoulou, P., Poliliou, S., Mourelatos, C., Lambropoulou, V., Lialiaris, T., (2010): Cytogenetic evaluation and DNA interaction studies of the food colourants amaranth, 
erythrosine and tartrazine. Food Chem. Toxicol., 48, 2934-2944. https://doi.org/10.1016/j.fct.2010.07.030

Neo A., Tan D., Ferguson A., Morris C., (2011): Investigation of the Effects of St John's Wort on Cancer and Drosophila. AOS-HCI Combined Research Paper, Hwa Chong Institution, Singapore.

Patterson, R. M., \& Butler, J. S. (1982). Tartrazine-induced chromosomal aberrations in mammalian cells. Food and Chemical Toxicology, 20(4), 461-465. https://doi.org/10.1016/s0278-6915(82)80113-0

Poul, M., Jarry, G., Elhkim, M. O., \& Poul, J. M. (2009). Lack of genotoxic effect of food dyes amaranth, sunset yellow and tartrazine and their metabolites in the gut micronucleus assay in mice. Food and chemical toxicology, 47(2), 443-448. https://doi.org/10.1016/j.fct.2008.11.034

Sarıkaya R., Selvi M., Akkaya N., Acar M., Erkoc F., (2010): The effect of food dyes of different concentrations on the percentage of living in Drosophila melanogaster ( $m w h \times$ flr). Süleyman Demirel Üniversitesi Fen Dergisi, 5, 38-46.

Sasaki, Y.F., Kawaguchi S., Kamaya A., Ohshita M., Kabasawa K., Iwama K., Taniguchi K., Tsuda S., (2002): The comet assay with 8 mouse organs: results with 39 currently used food additives. Mutat. Res.-Genet. Toxicol. Environmental Mutagenesis, 519 (1-2), 103-119.

https://doi.org/10.1016/s1383-5718(02)00128-6

Topsoy H., (1990): Quantification of synthetic paints added to some sugary foods. Ankara Üniversitesi Sağlık Bilimleri Enstitüsü Yayınları, Ankara, Türkiye.

Türkoğlu S., Benli D., Şahin D., (2015): The effects of five food dyes on the longevity of Drosophila melanogaster. Fresenius Environmental Bulletin, 24(9), 2830-2836.

Tripathy, N. K., Patnaik, K. K., \& Nabi, M. J. (1989). Genotoxicity of tartrazine studied in two somatic assays of Drosophila melanogaster. Mutation Research/Genetic Toxicology, 224(4), 479-483. https://doi.org/10.1016/0165-1218(89)90073-6

Uysal H., Genç S., Ayar A., (2017): Toxic effects of chronic feeding with food azo dyes on Drosophila melanogaster Oregon R. Scientia Iranica C, 24(6), 3081-3086.

https://dx.doi.org/10.24200/sci.2017.4523

Uysal H., Kara A.A., Algur O.F., Dumlupınar R., Aydoğan M.N., (2007): Recovering effects of aqueous extracts of some selected medical plants on the teratogenic effects during the development of D. Melanogaster. Pak J Biol Sci., 15, 10(10), 1708-1712. https://doi.org/10.3923/pjbs.2007.1708.1712

Yaman M., (1996): Investigation of synthetic dye amount added to some foodstuffs. Gazi Üniversitesi Sosyal Bilimleri Enstitüsü Yayınları, Ankara, Türkiye.

Yentür G., Ekşi A., Bayhan A., (1996): Investigation of the amount of synthetic dye in cake decorations and some candies provided from Ankara market. Ankara Üniversitesi Veteriner Fakültesi Dergisi, 43, $479-484$.

Zhou B., Wu L.J., Tashiro S., Onodera S., Uchiumi F., Ikejima T., (2006): Silibinin Protects Rat Cardiac Myocyte from Isoporoterenol-Induced DNA Damage Independent on Regulation of Cell Cycle. Biological and Pharmaceutical Bulletin, 29 (9), 1900-1905.

Zordan M., Osti M., Pesce M., Costa R., (1994): Chloral hydrate is recombinogenic in the wing spot test in Drosophila melanogaster. Mutat. Res., 322, 111-116. https://doi.org/10.1016/0165-1218(94)00017-4 